\title{
21.ネパールにおける環境污染状況及び住民の環境意識に関する研究 \\ PERCEPTION OF ENVIRONMENTAL PROBLEMS IN NEPALESE OF THREE ECOLOGICALLY DIFFERENT AREAS
}

\author{
二渡 了*・柏崎 浩*・濱井妙子** \\ Tohru FUTAWATARI*, Hiroshi Kashiwazaki* and Tacko Hamai**
}

\begin{abstract}
Nepal is one of the least developed countries in the world. Environmental pollution and its influence on humane health are the growing concern of national health planners. The purpose of this study was to examine the relationship between the resource use and environmental perception of inhabitants, and to discuss the environmental sustainability in Nepal. We carried out a preliminary study on environmental pollution and a questionnaire survey in three districts, Kathmandu, Mustang, and Rupandehi, which were selected with a consideration of geographical, ecological and urban-rural conditions in the country. Environmental concentrations and personal exposure levels of nitrogen dioxide (NO2) and volatile organic compounds (VOCs) were measured by using small passive air samplers/gas tubes, and drinking water quality was examined by a portable test-kit. Using questionnaire, we collected information for a total of 585 persons through local interviewers on residential conditions, agricultural activity, environmental conditions, health effect, and attitude toward environmental sustainability. We found that the environmental concentrations and personal exposure levels of $\mathrm{NO} 2$ and total VOCs differed by regions, reflecting the different type of emission sources. Although the levels were generally lower than the international guideline, the indoor levels of $\mathrm{NO}_{2}$ and total VOCs were commonly higher in three districts than outdoor levels. Some of the samples from the potable water sources in urban area were unexpectedly contaminated with a high level of nitrate. Analysis of the response to questionnaire indicated marked regional differences in subjects' environmental perception and focus on the major environmental problems.
\end{abstract}

KEYWORDS; environmental problems in Nepal, environmental resources, air quality, water quality, questionnaire survey

\section{1. はじめに}

ネパールのような開発途上国における資源消費やインフラストラクチャー未整備のために生じている環境污 染は, そこで生活する住民の健康に大きな影響を与えている。こうした資源消費や環境污染, それに起因する 健康影響は, それぞれの次元で住民の意識や行動と関係を持っている。一方では, 環境影響の経済的価值に関 する検討が活発に行われている[1]。このような研究の成果として, 環境保全施策策定段階において環境勘定 を活用し, 効果的な環境保全施策を展開していく必要がある。また, 世界資源研究所は健康と環境に関する新 しい指標を開発し, 開発途上国における環境による健康リスクを表すものとしている[2]。開発途上国指標は, 大気, 水, 栄養の 3 分野の環境による健康リスクの尺度を集計したものである。このような環境勘定や開発途 上国指標を用いて, 開発途上国の地域開発に関連する環境や住民の健康影響について検討することは, 環境政 策や保健政策分野での意思決定プロセスを支援する基礎データとして役立つことが期待される。さらには, そ こでの地域住民の環境や健康に対する意識形成過程に関する検討においても有効となる。

本研究では, ネパールの都市部及び農村部における環境污染状況を明らかにするとともに, これらの地域に 居住する人々の資源消費活動や生産活動について, 環境資源の持続性の側面から地域開発のあり方及び環境政 策の方向について検討する。なお，ネパール現地調査は，1998年 7 月 18 日から 8 月 16 日までの間で実施し た。その間，環境試料の採取・分析ならびに関係資料の収集，住民を対象としたアンケート調査を行った。

\section{2. 対象地域の特性と社会経済の状況}

\section{1 対象地域}

ネパールは, 北を中国チベット,その他の三方をインドに囲まれた, 東西に細長い国土を持つ内陸国である。 その地形はヒマラヤ山脈を含む北部の山岳地帯, 中部の丘陵地, 南部の平野(タライ)と変化に富み, 総人口約

* 産業医科大学産業保健学部 School of Health Sciences, University of Occupational and Environmental Health. Japan ** 静岡県立大学看護学部 School of Nursing Sciences, Shizuoka Prefectural University 
2100 万人で, 多種多様な民族が異 なった言語を持ち生活している。ネ パールの一般的なイメージとしては, ヒマラヤ山脈などの豊かな観光資源 を有する国としての側面があるが, 経済開発の観点からは, 非常に厳し い現実が横たわっている。ネパール は元来農業国ではあるが，山岳国と しての険しい地形のために農耕適地 が少なく，灌溉設備も十分に整備さ れていないため, 生産性は低レベル にとどまっている。また, 水資源以外 に目立った天然資源がないこと，運 輸・通信・電力・水供給などの基礎的

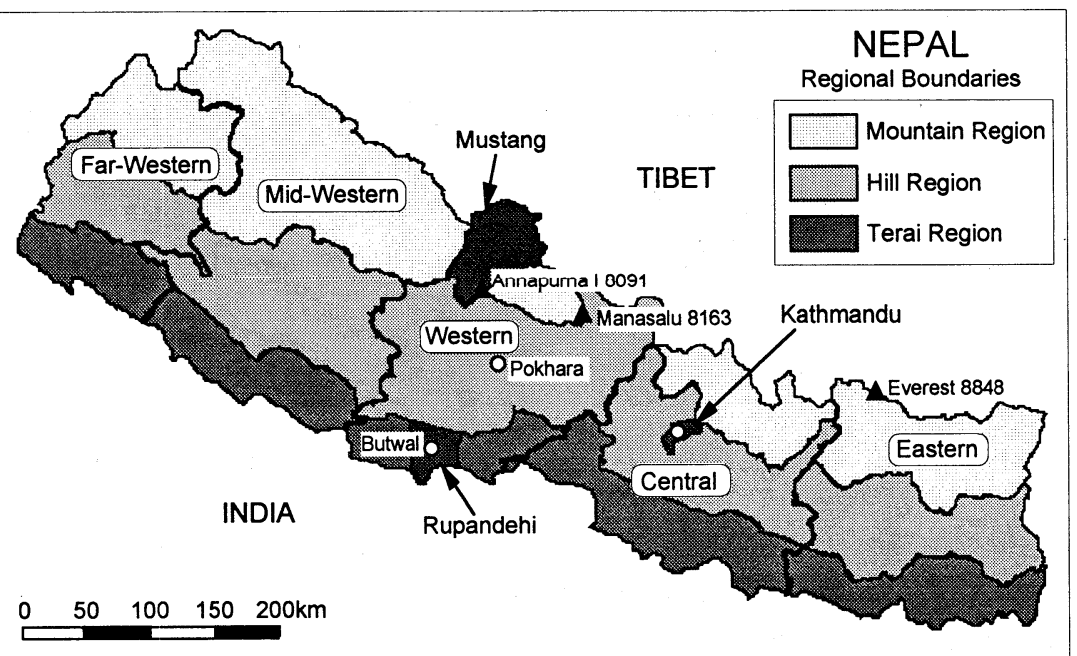

図 1 調查対象地域 なインフラストラクチャーがアジアの中でも極めて低い水準にあること, 国民の教育機会がそしく人的資源が 限られていることなどが経済開発上の大きな足かせとなっている[3]。ネパールの経済水準は, 一人当たり所 得が US\$220(1995/96 年)にすぎず，世界でも有数の最貧国のままの状態にあり, 経済開発を進めるに際し ての諸条件は苛酷である。下層 20\%の国民は国民所得のわずか $3.7 \%$ しなく，上位 $10 \%$ の国民がその $50 \%$ を得ており，人口の $45 \%$ 分困ライン以下の水準で生活をしている[4]。

ネパールの基本となる行政区域は 75 の District であり, さらにそれらが 3,912 のVDC(Village Development Committee)と58の Municipalityに分けられている。ネパールでは, その地形的な特性から Mountain, Hill, Teraiの 3 つのEcological Regionに分けられている。さらに, Eastern, Central, Western, Mid-western, Far-westernの 5 つの Development Regionに区分されており，75の Districtをこれらに したがって区分すると 15 の地域に分けることができる。

今回対象としたのは, Kathmandu, Mustang, そしてRupandehiの 3 つの Districtであり, 現地におい て環境試料の採取及びアンケート調査を行った。図 1 に示すように Kathmandu は Central の Hill Region, Mustang はWestern の Mountain Region，そして Rupandehi はWestern の Terai Region に属する。

\section{2 人口・経済の動向}

ネパールは多民族国家であり, その構成も地域によって異なる。自然条件も含めて考えると, 生活や農業生 産の様式も地域によって差異が見られる。ここでは, "Statistical Year Book of Nepal 1997"[5]の統計デー 夕を用い, 今回現地調査を行った地域に焦点をあてながら, ネパールの社会・経済の状況について概観する。

表 1 に示すように, Kathmanduでは, 1981 年に 42.2 万人であった人口が 1991 年に 67.5 万人に増え, 1.60 倍になっている。Mustang では同様に 1.3 万人が 1.4 万人に(1.11 倍), Rupandehi では 37.9 万人が 52.2 万 人に(1.38 倍)増えている。なお, 全国では 10 年間で 1.23 倍の人口増加である。全国で 1.5 倍以上の人口増加 を示している Districtは, Kathmanduの他に3つのDistricがあり, そのうち2つはFar-western の Terai Region に位置する District である。

一方, 人口密度(1991年)では, Kathmanduが 1,710 人 $/ \mathrm{km}^{2}$ と最も高く, Mustangは 4 人 $/ \mathrm{km}^{2}$, Rupandehi が 384 人 $/ \mathrm{km}^{2}$ である。全国的には，首都 Kathmandu 周辺を除けば, Mountain Region の District で 28 人 $/ \mathrm{km}^{2}$ と低く, Terai Region では 254 人 $/ \mathrm{km}^{2}$ と高い人口密度を示す。Hill Regionの District は 137 人 / $\mathrm{km}^{2}$ であり, 両者の中間となっている。 人口と面積の構成からは, 国土面積の $35.2 \%$ Mountain Region に人口の 7.8\%が住み, Hill Regionでは国土面積 の $41.7 \%$ に人口 $45.5 \%$, Terai

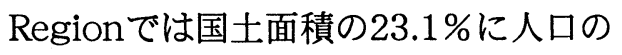
46.7\%が住んでいるといえる。このよ

表 1 対象地域の人口・面積・人口密度

\begin{tabular}{lrrrr}
\hline District & \multicolumn{1}{c}{ Nepal } & Kathmandu & Mustang & Rupandehi \\
\hline Population in 1981 & $15,022,789$ & 422,237 & 12,930 & 379,096 \\
Population in 1991 & $18,491,107$ & $\mathbf{6 7 5 , 3 4 1}$ & 14,292 & $\mathbf{5 2 2 , 1 5 0}$ \\
Population Increase in & 1.23 & 1.60 & 1.11 & 1.38 \\
1981 to 1991 & 147,181 & 395 & 3,573 & 1,360 \\
Area [sq. km] & 102 & 1,069 & 4 & 279 \\
Population Density in 1981 & 126 & 1,710 & 4 & 384 \\
Population Density in 1991 & & & &
\end{tabular}


うに, ネパールでは人口増加や人口密度に地域的な特色が見られ, 南部平原地帯での人口増加が著しい。

次に, 全国の宗教別人口では, Hinduが 86.5\%と最も多く, 続いて Bauddha 7.8\%, Islam 3.5\%である。 Kathmanduでは, Hindu 78.5\%, Bauddha 20.0\%であり, 全国レベルに比べて Bauddha の比率がやや多 くなっている。Mustang では, Hindu 22.2\%, Bauddha 77.6\%であり, Bauddha の方がかなり多い。 Rupandehi は, Hinduが90.1\%とほとんどを占め, 全国レベルよりもその比率が高い。また, 母語別人口に 関して見ると，全国では Nepali 50.3\%，Maithali 11.9\%，Bhojpuri 7.5\%の順である。Kathmanduでは， Nepaliが51.7\%であり, Newariも34.6\%と多い。 Mustangでは, Nepaliは32.5\%であり, Sherpa 38.1\%, Thakali 15.6\%, Gurung 10.4\%と全国レベルではかなり少数となっている母語人口が多い。Rupandehi で は, Bhojpuri 50.6\%が Nepali 32.5\%よりも多い。このように，ネパールでは地域によって宗教や民族構成 が大きく異なり，これが生活や農業生産様式に地域的な変化を与えることになっている。

全国では識字人口 $39.3 \%$, 非識字人口 $59.9 \%$ でり, 非識字人口の方が多い。また，女性の方が男性より も識字率が低い。3 地域については，識字人口が，それぞれ Kathmandu 69.6\%, Mustang 48.4\%, Rupandehi 39.8\%である。いずれも全国レベルよりは高いが，30～60\%の非識字人口が存在する。

職業別人口では，全国で農林水産業就労者が $81.1 \%$ と最も多い。これに続くのは，サービス業 $6.2 \%$, 製造 業 $4.2 \%$ と少数であり, ネパールの主要産業が農業となっていることを示している。Kathmanduでは, 農林 水産業就労者は $25.5 \%$ であり，全国レベルに比べるとかなり少ない。製造業 $21.3 \%$, 販売業 $13.8 \%$, サービ 不業 $13.6 \%$ のうに農林水産業以外の職業に就労する人口も多く, 都市化が進んでいることがわかる。一方, Mustang やRupandehi では，農林水産業就労者がそれぞれ 73.3\%，76.7\%であり，全国レベルよりはやや 少ないが, これらの地域は主として農業に依存しているといえる。

続いて, 経済状況について検討する。ネパールのGDP(実質)は年々増加しているものの, その成長率は大き く変化している。1984/85 年から 1996/97 年までの 12 年間の平均成長率は $4.8 \%$ となる。産業部門別では, 農林水産業の占める割合が高いが, その成長率は低位であり, 12 年間の平均成長率は $3.0 \%$ ある。これに対 して, 製造業や建設業等の生産額は農林水産業に比べて少ないけれども, 成長率は概ね高位であり, 平均成長 率はいずれも $5 \%$ を越える。

産業部門別GDPの推移を図 2 に示す。農林水産業の構成 比は年々減少し，近年は $41 \%$ 程度である。これに対して, 製 造業は $1984 / 85$ 年 $5.7 \%$ で あったものが 1996/97 年には 8.9\%に増加している。建設業 や商業・レストラン・ホテル 業, 運輸・通信・倉庫業, 金融・ 不動産業, 地域・社会サービス 業は,いずれも漸増している。 なお, 地域別の生産額のデー タが得られなかったため, District単位での経済発展につ

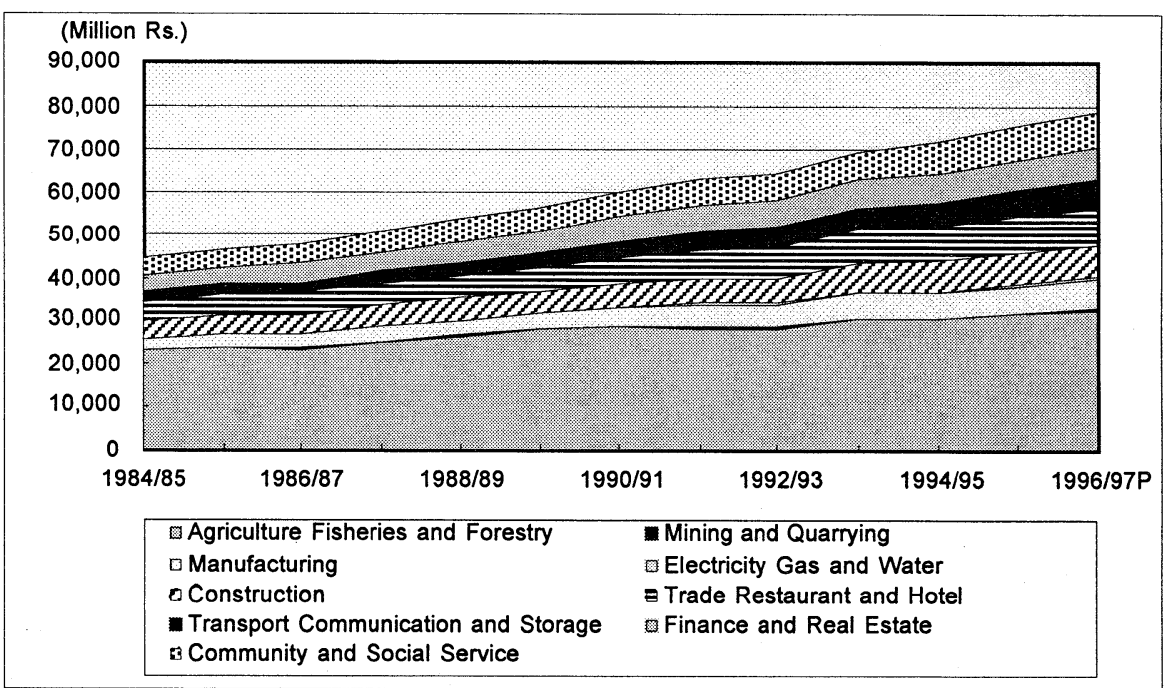

図2 産業部門別 GDP（実質）の推移 いての検討はできなかった。地域的な産業構造では, 都市部で中小規模の製造業・流通業・観光業, 地方・農 村部では自給自足型農業が並存した形態になっている。

\section{3. ネパールにおける環境污染状況}

\section{1 調查方法}

環境污染項目として大気と水質に関する調査を行った。大気に関する測定項目は, 二酸化窒素 $\left(\mathrm{NO}_{2}\right)$ 及び 揮発性有機化合物(VOCs: Volatile organic compounds)である。サンプラー $\left(\mathrm{NO}_{2} ;\right.$; パッシブガスサンプ ラー, 東洋濾紙社製, VOCs ; パッシブガスチューブ, 柴田科学社製）を個人及び室内, 屋外に取り付け, 約2 4 時間曝露し, ガスを捕集した。捕集後のサンプラーを容器に封入し, 後日 (帰国後) 所定の方法で各 
測定項目を分析した。今回個別に定量したVOCs物質は, ベンゼン, トルエン, p-キシレン, エチルベンゼ ン, デカン, ドデカン, メチルイソブチルケトン(MIBK: methyl isobutyl keton)である。さらに, TVOC (Total VOCs)濃度をGC/MS定量結果の総面積からトルエン換算により定量した。

水質測定では, 今回の調査が海外現地調査であったことから, 水質簡易測定キット（パックテスト, 共立 理化学研究所製）を用いて行った。水道水，井戸水等を $100 \mathrm{ml}$ 㳢リビンに採取し，速やかにパックテストを 実施して水質を測定した。測定項目はpH, アンモニア $\left(\mathrm{NH}_{4}\right)$, 硝酸 $\left(\mathrm{NO}_{3}\right)$, リン酸 $\left(\mathrm{PO}_{4}\right)$, 化学的酸素要求 量(COD)である。

\section{2 大気環境測定結果}

大気環境測定結果を表 2 に示す。個人, 室内, 屋外の順に各地域毎の結果をまとめており, ネパール 3 地 域全体での平均値等を示す。比較のために, 同時期に国内北九州地区で測定された結果 [ 6] も示す。ここで は，平均値及び標準偏差の算出にあたっては検出限界以下(ND)は0として計算した。

まず，個人について見ると， 表 2 大気環境測定結果

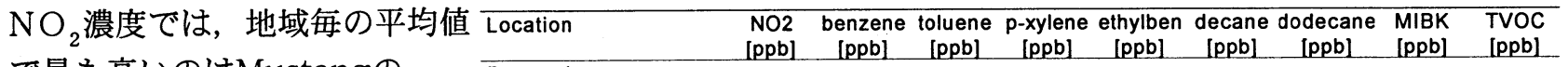

で最も高いのはMustangの

$9.26 \mathrm{ppb} ゙$ る。しかし, 地域 によって大きな差はなく, いず れの地域も北九州地区の平均濃 度より低い。ベンゼンが測定さ れたのは, Kathmanduだけで ある。トルエン等のVOCs 各項 目やTVOCでは, ネパール 3 地 域の方が北九州地区よりも全般 的に高濃度となっている。とく に, TVOCの平均濃度は, 北九 州地区(69.4ppb)の1.7〜2.8倍 であり, 各地域での最高濃度も 318〜 517ppb程度と高い。

次に, 室内では, $\mathrm{p}$-キシレン 及びエチレン, MIBKを除いて いずれの項目でもネパール 3 地 域での濃度が北九州地区に比べ て高い。とくに, Mustang及び RupandehiでのNO

Kathmanduのベンゼン, トル エンの濃度は, ネパール 3 地域 でも個人や屋外の場合と比べて 高い。また，いずれの地域でも TVOCの濃度が北九州地区より も高くなっている。これらは, 室内調理場で使用されている燃 料(主に燃料用木材や灯油)の影 響によるものと考えられる。さ らに, $\mathrm{NO}_{2}$ やベンゼンの結果に ついて考えると, 室内調理場で 使用されている燃料が, Kathmanduでは灯油, Mus-

\begin{tabular}{|c|c|c|c|c|c|c|c|c|c|c|}
\hline \multirow{2}{*}{\multicolumn{11}{|c|}{ Personal }} \\
\hline & & & & & & & & & & \\
\hline \multirow{3}{*}{$(\mathrm{N}=7)$} & Mean & 6.10 & 3.02 & 23.63 & 10.05 & 9.59 & 7.15 & $\begin{array}{l}10.77 \\
1471\end{array}$ & $\begin{array}{r}18.45 \\
3.66\end{array}$ & 195.19 \\
\hline & SD & 0.96 & $\begin{array}{r}6.66 \\
18.03\end{array}$ & $\begin{array}{l}15.17 \\
55.90\end{array}$ & 6.39 & $\begin{array}{r}2.98 \\
13.40\end{array}$ & $\begin{array}{r}8.68 \\
22.22\end{array}$ & $\begin{array}{l}14.71 \\
40.74\end{array}$ & $\begin{array}{r}3.66 \\
22.30\end{array}$ & $\begin{array}{l}160.66 \\
517.42\end{array}$ \\
\hline & $\begin{array}{l}\text { Max } \\
\text { Min }\end{array}$ & $\begin{array}{l}7.63 \\
4.86\end{array}$ & $\begin{array}{r}18.03 \\
0.00\end{array}$ & $\begin{array}{r}55.90 \\
8.50\end{array}$ & $\begin{array}{r}20.30 \\
3.22\end{array}$ & $\begin{array}{r}13.40 \\
5.78\end{array}$ & & $\begin{array}{r}40.14 \\
0.00\end{array}$ & 13.51 & 71.02 \\
\hline \multirow{4}{*}{$\begin{array}{l}\text { Mustang } \\
(\mathrm{N}=5)\end{array}$} & Mean & 9.26 & 0.00 & 11.29 & 7.41 & 0.01 & 12.21 & 11.08 & 13.36 & 153.54 \\
\hline & SD & 4.53 & 0.00 & 7.26 & 11.28 & 0.01 & 14.76 & 8.30 & 10.23 & 122.65 \\
\hline & Max & 15.90 & 0.00 & 17.93 & 26.71 & 0.02 & 37.91 & 22.87 & 25.97 & 345.07 \\
\hline & Min & 3.92 & 0.00 & 0.00 & 0.00 & 0.01 & 0.00 & 0.00 & 0.00 & 10.56 \\
\hline \multirow{4}{*}{$\begin{array}{l}\text { Rupandehi } \\
(\mathrm{N}=5)\end{array}$} & Mean & 8.79 & 0.00 & 6.35 & 1.77 & 8.99 & 0.96 & 2.69 & 12.91 & 117.75 \\
\hline & SD & 5.76 & 0.00 & 3.64 & 2.47 & 2.89 & 2.15 & 3.19 & 9.07 & 113.99 \\
\hline & Max & 18.10 & 0.00 & 8.66 & 5.05 & 12.82 & 4.81 & 7.56 & 20.19 & 317.77 \\
\hline & Min & 3.48 & 0.00 & & 0.00 & 5.82 & 0.00 & 0.00 & 0.00 & 37.53 \\
\hline \multirow{4}{*}{$\begin{array}{l}\text { Overal } \\
(\mathrm{N}=17)\end{array}$} & Mean & 7.82 & 1.24 & 14.92 & 6.84 & 6.60 & 6.82 & 8.48 & 15.32 & 160.17 \\
\hline & SD & 4.00 & 4.36 & 12.77 & 7.83 & 4.97 & 10.18 & 10.76 & 7.69 & 133.42 \\
\hline & $\operatorname{Max}$ & 18.10 & 18.03 & 55.90 & 26.71 & 13.40 & 37.91 & 40.74 & 25.97 & 517.42 \\
\hline & Min & 3.48 & 0.00 & 0.00 & 0.00 & 0.01 & 0.00 & 0.00 & 0.00 & 10.56 \\
\hline \multirow{4}{*}{$\begin{array}{l}\text { Kitakyushu } \\
(\mathrm{N}=26)\end{array}$} & Mean & 12.66 & 0.00 & 4.98 & 1.31 & 7.49 & 0.36 & 0.43 & 25.28 & 69.35 \\
\hline & SD & 7.73 & 0.00 & 5.59 & 3.24 & 4.01 & 0.93 & 1.52 & 33.47 & 33.27 \\
\hline & Max & 35.13 & 0.00 & 18.85 & 11.90 & 16.18 & 3.57 & 6.28 & 183.86 & 198.74 \\
\hline & Min & 2.74 & 0.00 & 0.00 & 0.00 & 0.00 & 0.00 & 0.00 & 0.00 & 31.76 \\
\hline \multirow{5}{*}{$\begin{array}{l}\text { In-door } \\
\text { Kathmandu } \\
(\mathrm{N}=9)\end{array}$} & & & & & & & & & & \\
\hline & Mean & 12.49 & 18.76 & 43.80 & 10.60 & 11.38 & 7.70 & 9.90 & 17.64 & 256.99 \\
\hline & SD & 11.49 & 44.55 & 32.69 & 8.54 & 4.86 & 11.61 & 12.77 & 6.24 & 260.63 \\
\hline & Max & 37.50 & 135.69 & 109.40 & 23.28 & 21.94 & 32.00 & 36.04 & 25.81 & 875.59 \\
\hline & Min & 4.02 & 0.00 & 7.32 & 0.00 & 6.38 & 0.00 & 0.00 & 8.54 & 58.94 \\
\hline \multirow{4}{*}{$\begin{array}{l}\text { Mustang } \\
(\mathrm{N}=5)\end{array}$} & Mean & 32.08 & 8.11 & 16.78 & 7.27 & 0.01 & 14.22 & 16.61 & 10.91 & 221.70 \\
\hline & SD & 23.54 & 12.13 & 11.27 & 7.43 & 0.01 & 14.48 & 18.87 & 5.56 & 202.27 \\
\hline & Max & 60.70 & 27.19 & 27.84 & 17.05 & 0.02 & 37.42 & 48.79 & 18.44 & 548.82 \\
\hline & Min & 4.42 & 0.00 & 0.00 & 0.00 & 0.01 & 0.00 & 0.00 & 5.64 & 27.23 \\
\hline \multirow{4}{*}{$\begin{array}{l}\text { Rupandehi } \\
(\mathrm{N}=4)\end{array}$} & Mean & 66.30 & 0.00 & 18.34 & 3.05 & 8.89 & 6.13 & 11.97 & 19.36 & 182.65 \\
\hline & SD & 96.12 & 0.00 & 12.89 & 6.09 & 1.62 & 10.27 & 17.27 & 11.79 & 140.72 \\
\hline & Max & 210.20 & 0.00 & 34.52 & 12.19 & 10.49 & 21.37 & 37.60 & 32.17 & 382.39 \\
\hline & Min & 12.20 & 0.00 & 7.46 & 0.00 & 7.40 & 0.00 & 0.00 & 4.58 & 73.56 \\
\hline \multirow{4}{*}{$\begin{array}{l}\text { Overall } \\
(N=18)\end{array}$} & Mean & 29.89 & 11.63 & 30.64 & 8.00 & 7.67 & 9.16 & 12.23 & 16.15 & 230.66 \\
\hline & SD & 47.92 & 32.11 & 27.31 & 7.96 & 6.04 & 11.93 & 14.89 & 7.86 & 214.53 \\
\hline & Max & 210.20 & 135.69 & 109.40 & 23.28 & 21.94 & 37.42 & 48.79 & 32.17 & 875.59 \\
\hline & Min & 4.02 & 0.00 & 0.00 & 0.00 & 0.01 & 0.00 & 0.00 & 4.58 & 27.23 \\
\hline \multirow{4}{*}{$\begin{array}{l}\text { Kitakyushu } \\
(\mathrm{N}=22)\end{array}$} & Mean & 13.39 & 0.00 & 5.69 & 17.64 & 13.19 & 1.19 & 1.44 & 36.58 & 146.79 \\
\hline & SD & 8.30 & 0.00 & 8.63 & 34.20 & 17.57 & 2.43 & 2.19 & 58.97 & 231.93 \\
\hline & $\operatorname{Max}$ & 40.60 & 0.00 & 32.92 & 101.22 & 60.69 & 9.41 & 5.63 & 217.25 & 963.95 \\
\hline & Min & 3.80 & 0.00 & 0.00 & 0.00 & 0.00 & 0.00 & 0.00 & 0.00 & 18.29 \\
\hline \multicolumn{11}{|l|}{ Out-door } \\
\hline Kathmandu & Mean & 9.29 & 3.06 & 26.29 & 6.00 & 8.49 & 1.61 & 2.81 & 23.72 & 118.28 \\
\hline & SD & 2.89 & 4.33 & 22.27 & 5.46 & 3.1 & 1.3 & 2.41 & 7.04 & 53.40 \\
\hline & $\operatorname{Max}$ & 14.30 & 14.53 & 75.12 & 14.54 & 12.87 & 3.79 & 7.09 & 37.42 & 243.56 \\
\hline & Min & 4.80 & 0.00 & 7.22 & 0.00 & 4.08 & 0.0 & 0.00 & 14.59 & 63.43 \\
\hline Mustang & Mean & 5.50 & 0.00 & 2.41 & 0.00 & 0.01 & 0.00 & 2.34 & 22.40 & 68.92 \\
\hline$(\mathrm{N}=2)$ & SD & & & & & & & & & \\
\hline & $\operatorname{Max}$ & 9.37 & 0.0 & 4.81 & 0.00 & & 0.0 & & & 72.03 \\
\hline & Min & 1.62 & & 0.0 & 0.00 & 0.0 & 0.00 & 0.0 & 21.22 & 65.81 \\
\hline Rupandehi & Mean & 4.84 & 0.00 & 1.24 & 3.19 & 5.12 & 1.44 & 3.16 & 20.52 & 177.30 \\
\hline$(\mathrm{N}=3)$ & SD & 6.26 & 0.00 & 2.1 & 5.53 & 4.4 & 2.5 & 5.47 & 8.24 & 147.30 \\
\hline & $\operatorname{Max}$ & 12.00 & 0.00 & 3.7 & 9.57 & 7.7 & 4.3 & 9.47 & 29.31 & 341.72 \\
\hline & Min & 0.37 & 0.0 & 0.0 & 0.8 & 0.0 & 0. & 0.0 & 12.97 & 57.38 \\
\hline Overall & Mean & 7.89 & 2.04 & 18.09 & 4.64 & 6.6 & 1.3 & 28 & 22.91 & 123.51 \\
\hline$(N=15)$ & SD & 4.16 & 3.78 & 21.55 & 5.32 & 4.27 & 1.5 & 2.97 & 6.59 & 77.45 \\
\hline & Max & 14.30 & 14.53 & 75.12 & 14.54 & 12.87 & 4.32 & 9.47 & 37.42 & 341.72 \\
\hline & Min & 0.37 & 0.0 & 0. & 0.0 & 0.0 & 0.0 & 0.00 & 12.97 & 57.38 \\
\hline Kitakyushu & Mean & 13.40 & 0.00 & 3.71 & 0.00 & 5.86 & 1.61 & 0.94 & 16.29 & 59.26 \\
\hline$(\mathrm{N}=19)$ & SD & 7.62 & 0.00 & 4.89 & 0.00 & 2.83 & 3.92 & 1.97 & 8.65 & 17.69 \\
\hline & $\mathrm{Ma}$ & 29.08 & 0.00 & 16.13 & 0.00 & 12.24 & 15.64 & 6.34 & 35.93 & 85.73 \\
\hline & $\mathrm{Mi}$ & 3.92 & 0.00 & 0.00 & 0.00 & 0.00 & 0.00 & 0.00 & 4.77 & 11.06 \\
\hline
\end{tabular}


tangでは灯油と燃料用木材，そしてRupandehiでは燃料用木材であったことが影響しているといえる。す なわち, 灯油はべンゼン, 燃料用木材は $\mathrm{NO}_{2}$ を燃焼時に排出しているとも考えられる。

屋外の結果では, いずれの項目もKathmanduでの濃度が高くなっている。MustangやRupandehiでは, $\mathrm{NO}_{2}$ やTVOCの濃度がやや高いといえるが，全般的には低濃度である。

以上のように, 大気污染状況について調査 3 地域ともに共通していえることは, 室内での污染物質として $\mathrm{NO}_{2}$ やTVOCの濃度が高いことである。しかし, 測定項目相互の関係から見た室内での污染状況は, 使用す る燃料の種類によって異なっている。一方, 屋外では, Kathmanduでベンゼンやトルエンの濃度が高かっ たが, MustangやRupandehiではそれらの濃度は低い。農村部では, 一般環境における大気污染はないと いえる。

\section{3 水啠測定結果}

水質測定結果を表 3 に示す。今回の調査では，飲料水を中心に調查を行った。

まず, pHでは, Kathmanduが6.5〜 7.5, Musutangが7.5〜8.5, Rupandehiが7.0〜8.0の範囲にあり, 山岳地域であるMusutangでやや高くなっている。

アンモニア濃度では, Kathmandu及びRupandehiにおいて, 10mg/1の濃度がそれぞれ4地点, 1地点で 観測された。また, Kathmandu及びRupandehiでは高濃度の硝 酸が測定されている。これらの地点では, リン酸濃度やC O D 濃 度も高かった。

Kathmanduでは, 各濃度が高い地点が数ヶ所あるが。これら は現地で実際に飲料水として用いられている井戸水や水道水であ り，その影響が心配される。一方, Musutangでは, 全般的に水 質は良好といえる。このMusutang (Kagbeni) では数年前に集 落を流れる河川（Kali Gandaki川の支川）上流を水源地とする水 道が整備されており, 山岳部で外部からの污染が少ないことから もこのような結果になったものと考えられる。しかし，集落内 10 ケ所程度に共有の水道場があるだけであり, まだ各家庭まで 直接配水はされていない。Rupandehiでは，地域共有あるいは 各家庭内の井戸(ハンドポンプ) を使用しており, 同農村部では上 水道は未整備である。今回調查を行った 3 地域では, Kathmandu及びRupandehiで数地点ずつWHOガイドライン值 (45 mg/1)を越える硝酸濃度が観測された。これは, 上水道の未 整備あるいは不完全な管理によるものと考えられるが，同時に排 水施設や衛生施設の整備も必要かと思われる。

表 3 水質測定結果 (地点数)

\begin{tabular}{|c|c|c|c|c|}
\hline Items & Range & $\begin{array}{l}\text { Kathmandu } \\
(\mathrm{N}=15)\end{array}$ & $\begin{array}{c}\text { Mustang } \\
(\mathrm{N}=11)\end{array}$ & $\begin{array}{l}\text { Rupandehi } \\
(\mathrm{N}=15)\end{array}$ \\
\hline \multirow[t]{6}{*}{$\mathrm{pH}$} & 6.5 & 4 & & \\
\hline & 7 & 3 & & 3 \\
\hline & 7.5 & 7 & 2 & 10 \\
\hline & 8 & & 7 & 2 \\
\hline & 8.5 & & 2 & \\
\hline & 9 & 1 & & \\
\hline \multirow{6}{*}{$\begin{array}{l}\mathrm{NH}_{4} \\
{[\mathrm{mg} / \mathrm{l}]}\end{array}$} & 0 & 7 & 3 & 4 \\
\hline & $0-0.5$ & & 8 & 7 \\
\hline & 0.5 & 2 & & 3 \\
\hline & 1 & & & \\
\hline & 2 & 1 & & \\
\hline & 10 & 4 & & 1 \\
\hline \multirow{5}{*}{$\begin{array}{l}\mathrm{NO} 3 \\
{[\mathrm{mg} / \mathrm{l}]}\end{array}$} & 1 & 5 & 11 & 10 \\
\hline & 2 & 5 & & 1 \\
\hline & 5 & 1 & & 1 \\
\hline & 10 & 1 & & 1 \\
\hline & 45 & 3 & & 2 \\
\hline \multirow{6}{*}{$\begin{array}{l}\mathrm{PO} 4 \\
{[\mathrm{mg} / \mathrm{l}]}\end{array}$} & 0.2 & 1 & 11 & 5 \\
\hline & 0.5 & 6 & & 7 \\
\hline & 1 & 1 & & 2 \\
\hline & 2 & 2 & & 1 \\
\hline & 5 & 1 & & \\
\hline & 10 & 3 & & \\
\hline \multirow{4}{*}{$\begin{array}{l}\text { COD } \\
{[\mathrm{mg} / \mathrm{l}]}\end{array}$} & $0,0-2,2$ & 2 & 9 & 11 \\
\hline & 5 & 8 & 1 & 2 \\
\hline & 10 & 4 & 1 & 1 \\
\hline & 20 & 1 & & 1 \\
\hline
\end{tabular}

\section{4. 住民の環境に対する意識と行動}

\section{1 調查方法}

アンケート調査は, KathmanduとTokha, Mustang, Rupandehi/Mun., Rupandehi/VDCの 5 地域 で行った。Kathmanduは，ネパールの首都として国内で最も開発が進んだ都市である。対象とした地域は その中心部であり商店街と住宅が混在した地区となっている。TokhaはKathmandu市街地の郊外に位置し た農村集落であり, Mustang(Kagbeni)は山岳地帯の集落である。また, Rupandehiはインドと国境を接す るDistrictであり, その都市部(Mun.) と農村部(VDC)の集落を対象とした。すなわち, Kathmanduと Rupandehi/Mun.は都市部，Tokha及びMustang，Rupandehi/VDCは農村部と位置づけられる。

アンケート調査項目は, 環境に対する住民の意識や行動に関する内容である。表 4 に主な調査項目を示 す。このような内容の質問をネパール語に翻訳した調查票を用い，調査員が回答者を訪問してインタビュー 形式で回答を記入するようにした。対象は調査地域に居住する回答可能な者全員である。なお, 個別の調査 員による回答への影響がないように調査員の教育ミーティングを随時行った。調查数は, Kathmandu 239 名, Tokha 93名, Mustang 90名, Rupandehi/Mun.51名, Rupandehi/VDC 112名, 合計585名である。 


\section{2 基本属性}

回答者の平均年齢, 性別, 続柄を表 5 に示 す。いずれの地域でも, 回答者の平均年齢は 40歳前後であり, Mustangが44.5歳と他地域 に比べてやや高く，40 歳代の回答が多くなっ ている。性別では, Kathmandu, Tokhaで女 性が, Mustang, Rupandehi/VDCで男性が 多く, Rupandehi/Mun.ではほぼ同数となっ ている。世帯主との続柄でも, Kathmanduで 配偶者が多いが, その他の地域では世帯主本人 が最も多い。なお, 今回のアンケート調査で 帯を対象に調査を行っており，調査結果がそれぞれの地域世帯母集団の特性に基づいているものと考えられ る。

次に, 表 6 に収入及び土地・家畜の所有状況を示す。各地域での平均年収が最も高いのはKathmanduで あり, 以下, Tokha, Rupandehi/Mun., Mustang, Rupandehi/VDCの順である。Kathmanduの年収 最高值は高水準であるが，最低值は各地域で $1,200 \sim 3,000$ Rs.である。なお，調査時点で1US $\$=66$ Rs.であ り，1Rs.=約2円である。TokhaやMustangでは，住宅地以外に農地を所有する人が他地域に比べて多い。

TokhaやMustangでは，家畜を所有する世帯が80\%前後とかなり多い。これに対して，Kathmanduや Rupandehi/Mun., Rupandehi/VDCでは20〜40\%の世帯が所有しているだけである。Kathmanduや Rupandehi/Mun.は都市部であり, 家畜の所有が困難なためである。家 畜の種別にその飼育数を見ると， Tokhaではバッファロー及びウシを 所有する世帯が26\%あるが，その頭 数は少ない。Mustangでは種々の家 畜を所有しており， ウシを所有する 世帯が $83 \%$ と最も多く，その次がウ マの $54 \%$ あ゙あ。しかし，それらの 頭数は少ない。ヤギやヒツジを所有 する世帯は，それぞれ34\%，13\%と それほど多くはないが，その飼育数 は平均で50 前後であり, 相当の規模 をもった牧畜が行われているといえ る。

民族については，Kathmanduで は，Newarが約80\%である。また， TokhaはNewarの単一民族集落と なっている。MustangではGurung が8 $3 \%$ と最も多く，他に少数の民族 がいる。Rupandehi/Mun.では最も 多い民族でもMagar 24\%，Chhetri

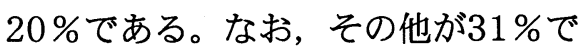
あり，その内訳でも各民族が数名し かおらず，Rupandehi/Mun.は多民 族の都市集落である。Rupandehi / VDCでは, Muslim 22\%, Brahmin

\begin{tabular}{|c|c|c|c|c|c|c|c|c|c|c|}
\hline Age & \multicolumn{2}{|c|}{$\begin{array}{l}\text { Kathmandu } \\
(\mathrm{N}=239)\end{array}$} & \multicolumn{2}{|c|}{$\begin{array}{l}\text { Tokha } \\
(\mathrm{N}=93)\end{array}$} & \multicolumn{2}{|c|}{$\begin{array}{l}\text { Mustang } \\
(\mathrm{N}=90)\end{array}$} & \multicolumn{2}{|c|}{$\begin{array}{l}\text { Rupandehi } \\
\text { /Mun. } \\
(\mathrm{N}=51)\end{array}$} & \multicolumn{2}{|c|}{$\begin{array}{l}\text { Rupandehi } \\
\text { NDC } \\
(N=112)\end{array}$} \\
\hline No. $1 \%$ & 230 & 96.2 & 92 & 98.9 & 89 & 98.9 & 49 & 96.1 & 109 & 97.3 \\
\hline Average / SD & 38.5 & 15.4 & 39.3 & 16.8 & 44.5 & 13.7 & 40.4 & 14.0 & 42.7 & 13.1 \\
\hline Max/Min & 82 & 15 & 78 & 17 & 74 & 20 & 72 & 20 & 75 & 16 \\
\hline \multicolumn{11}{|l|}{ Sex [No. \& \%] } \\
\hline Male & 97 & 40.6 & 34 & 36.6 & 60 & 66.7 & 26 & 51.0 & 70 & 62.5 \\
\hline Female & 142 & 59.4 & 59 & 63.4 & 30 & 33.3 & 25 & 49.0 & 42 & 37.5 \\
\hline \multicolumn{11}{|l|}{$\begin{array}{l}\text { Relation to Household } \\
\text { head [No. \& \%] }\end{array}$} \\
\hline Head & 53 & 22.2 & 40 & 43.0 & 68 & 75.6 & 25 & 49.0 & 64 & 57.1 \\
\hline Wife or Husband & 99 & 41.4 & 16 & 17.2 & 13 & 14.4 & 19 & 37.3 & 40 & 35.7 \\
\hline Son or Daughter & 41 & 17.2 & 3 & 3.2 & 5 & 5.6 & 6 & 11.8 & 6 & 5.4 \\
\hline Others & 20 & 8.4 & 5 & 5.4 & 3 & 3.3 & 1 & 2.0 & 1 & 0.9 \\
\hline NA & 26 & 10.9 & 29 & 31.2 & 1 & 1.1 & 0 & 0.0 & 1 & 0.9 \\
\hline
\end{tabular}

表 6 収入及び土地・家畜の所有状況

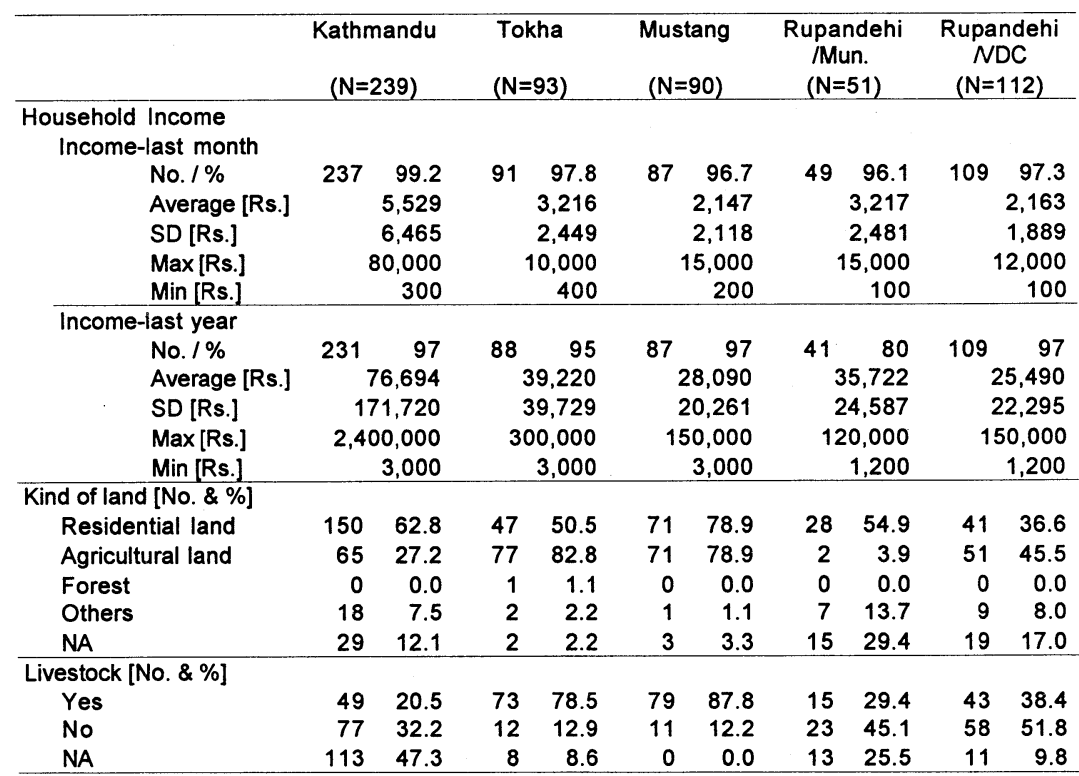


及びChhetriがともに15\%であり，ここも多民族の集落となっている。

いずれの地域でも平均世帯員数が5 人を越えており，20 歳代，30 歳代を中心とした家族構成となってい る。また, 単独世帯の方が複合世帯よりも多い。主要収入源として, Kathmanduでは会社員/サービス業 や商業との回答が多く, TokhaやMustangでは農業が80\%を越えている。Mustangでは商業も多く，農業 と商業との兼業が行われている。R u p a n d e h i / M u n . では会社員/サービス業が半数を超えている。

Rupandehi/VDCでは農業が45\%と最も多いが，会社員/サービス業や商業も30\%前後あり，兼業が行われ ているといえる。教育歴では, Tokha, Mustang, Rupandehi/VDCで「無就学」との回答が50〜 70\%程 度あり, 農村部における教育機会の少なさが表れている。都市部であるKathmanduやRupandehi/Mun.で は「無就学」との回答はそれぞれ 3 \% , $26 \%$ であり, 農村部地域に比べて低くなっている。識字程度でも こうした教育歴との関係がうかがわれ，「読み書き可能」との回答が, Kathmanduで $47 \%$ と高く，その他 の地域では8〜29\%と低い。

\section{3 居住環境について}

居住状況に関する結果を表 7 に示す。住宅の所有形態では, いずれの地域でも「自宅」との回答が最も多 い。KathmanduやRupandehi/Mun.では「借家」との回答もある。

上水道についてでは, Kathmandu及びRupandehi/VDCでは家庭内や地域共同の水道が使われており， Rupandehi/Mun.では「家庭内の水道」, TokhaやMustangでは「地域共同の水道」との回答が多い。

KathmanduやTokha

では調理場が 3 階あるい はそれより階上にあると の回答が多く, Mustang $\ln$ what type of House/room do you live? 表 7 居住状況

では $1 \cdot 2$ 階,

Rupandehi/Mun.及び

Rupandehi/VDCでは 1

階に調理場がある。これ らは, 各地域での住宅構 造の違いによるものであ る。Tokhaは農村集落で Where is the kitchen you usually use? ありながら，丘陵部にあ るため平地が少なく， 4 ・ 5 階建ての高層住宅 $\mathrm{NA}$ Kathmandu Tokha Mustang Rupandehi Rupandehi

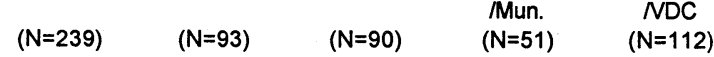

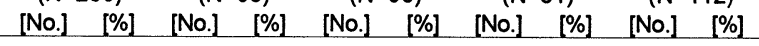
$\begin{array}{lllllllllll}\text { Inside house } & 160 & 66.9 & 29 & 31.2 & 25 & 27.8 & 18 & 35.3 & 7 & 6.3\end{array}$

となっている。また，トーInside house イレの場所として,

Kathmanduでは家屋内 との回答が $67 \%$ あるが, TokhaやMustang, Rupandehi/VDCといっ た農村部ではトイレがな いとの回答が多い。これ は, ネパールの文化とし てトイレがないためであ る。次に, 調理用の燃料 として, Kathmanduと Rupandehi/VDCでは石 油が主に使われ，Tokha やMustang, Rupandehi/VDCでは木

Own house
Offered house
Rented house
Others
NA
Piped taps in a house
Piped taps in a community
Kuwa/dug/well
Others
NA

$\begin{array}{rrrrrrrrrr}193 & 80.8 & 90 & 96.8 & 77 & 85.6 & 35 & 68.6 & 87 & 77.7 \\ 5 & 2.1 & 0 & 0.0 & 1 & 1.1 & 0 & 0.0 & 5 & 4.5 \\ 31 & 13.0 & 1 & 1.1 & 10 & 11.1 & 13 & 25.5 & 5 & 4.5 \\ 11 & 4.6 & 1 & 1.1 & 2 & 2.2 & 3 & 5.9 & 15 & 13.4\end{array}$

$\begin{array}{llllllllll}137 & 57.3 & 2 & 2.2 & 4 & 4.4 & 42 & 82.4 & 56 & 50.0\end{array}$

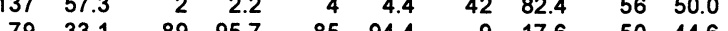

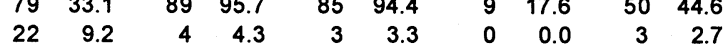
$\begin{array}{llllllllll}21 & 8.8 & 1 & 1.1 & 4 & 4.4 & 0 & 0.0 & 4 & 3.6\end{array}$ $\begin{array}{lllllllllll}\text { First floor } & 43 & 18.0 & 9 & 9.7 & 50 & 55.6 & 47 & 92.2 & 104 & 92.9\end{array}$ $\begin{array}{lllllllllll}\text { Second floor } & 28 & 11.7 & 12 & 12.9 & 34 & 37.8 & 3 & 5.9 & 0 & 0.0\end{array}$ $\begin{array}{lllllllllll}\text { Third floor } & 92 & 38.5 & 64 & 68.8 & 5 & 5.6 & 0 & 0.0 & 0 & 0.0\end{array}$ $\begin{array}{lllllllllll}\text { Others } & 74 & 31.0 & 7 & 7.5 & 0 & 0.0 & 1 & 2.0 & 8 & 7.1\end{array}$ $\begin{array}{lllllllllll}\text { Outside house } & 55 & 23.0 & 14 & 15.1 & 17 & 18.9 & 22 & 43.1 & 24 & 21.4\end{array}$

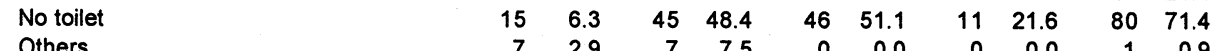

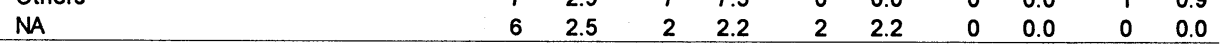
What type of fuel energy do you use for cooking? $\begin{array}{lrrrrrrrrrr}\text { Wood } & 48 & 20.1 & 68 & 73.1 & 88 & 97.8 & 4 & 7.8 & 94 & 83.9 \\ \text { Wastage of agriculture product } & 1 & 0.4 & 56 & 60.2 & 0 & 0.0 & 0 & 0.0 & 4 & 3.6\end{array}$

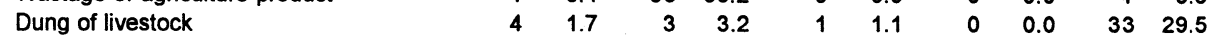
$\begin{array}{lrrrrrrrrrr}\text { Dung of livestock } & 4 & 1.7 & 3 & 3.2 & 1 & 1.1 & 0 & 0.0 & 33 & 29.5 \\ \text { Petroleum } & 197 & 82.4 & 25 & 26.9 & 26 & 28.9 & 49 & 96.1 & 36 & 32.1\end{array}$

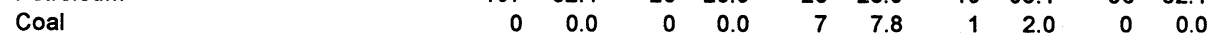

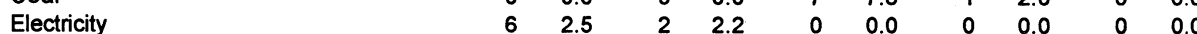
$\begin{array}{lllllllllll}\text { Others } & 5 & 2.1 & 9 & 9.7 & 0 & 0.0 & 0 & 0.0 & 0 & 0.0\end{array}$ NA How and from where do you usually get wood for fue? Purchase

Gathering from own forest

Gathering form the forest by getting permission from the owners Gathering from the public forest Others

$$
\text { NA }
$$

$\begin{array}{llllllllll}5 & 2.1 & 9 & 9.7 & 0 & 0.0 & 0 & 0.0 & 0 & 0.0 \\ 2 & 0.8 & 3 & 3.2 & 1 & 1.1 & 1 & 2.0 & 0 & 0.0\end{array}$

\begin{tabular}{rrrrrrrrrr}
\hline fuel? & & & & & & & & & \\
25 & 23.0 & 17 & 18.3 & 12 & 13.3 & 5 & 9.8 & 50 & 44.6 \\
27 & 11.3 & 40 & 43.0 & 66 & 73.3 & 0 & 0.0 & 7 & 6.3 \\
10 & 4.2 & 9 & 9.7 & 0 & 0.0 & 0 & 0.0 & 4 & 3.6 \\
& & & & & & & & & \\
1 & 0.4 & 9 & 9.7 & 14 & 15.6 & 0 & 0.0 & 38 & 33.9 \\
6 & 2.5 & 6 & 6.5 & 0 & 0.0 & 0 & 0.0 & 0 & 0.0 \\
156 & 65.3 & 23 & 24.7 & 4 & 4.4 & 46 & 90.2 & 17 & 15.2 \\
\hline \multicolumn{1}{l}{$\begin{array}{rrrr}\text { family? } \\
69\end{array}$} & 28.9 & 0 & 0.0 & 8 & 8.9 & 0 & 0.0 & 0 & 0.0 \\
30 & 12.6 & 10 & 10.8 & 57 & 63.3 & 6 & 11.8 & 4 & 3.6 \\
56 & 23.4 & 37 & 39.8 & 29 & 32.2 & 15 & 29.4 & 29 & 25.9 \\
18 & 7.5 & 31 & 33.3 & 2 & 2.2 & 22 & 43.1 & 70 & 62.5 \\
26 & 10.9 & 11 & 11.8 & 9 & 10.0 & 7 & 13.7 & 7 & 6.3 \\
46 & 19.2 & 8 & 8.6 & 1 & 1.1 & 2 & 3.9 & 2 & 1.8 \\
\hline
\end{tabular}


材を使用するところが多い。Tokhaでは「非可食部農産物」との回答も60\%ある。そして, TokhaやMustangでは, 燃料用木材を購入したり, 自分が所有する森林から収集している。廃棄物の処理では, 「決めら れた所定の場所へ廃棄する」との回答が多いのがKathmanduとMustangであり, TokhaやRupandehi／ Mun., Rupandehi/VDCでは適当に勝手な場所へ棄てられている。

このように，居住環境に関して各地域による違いが見られる。同じ農村集落であるTokhaやMustang， Rupandehi/VDCでは, トイレの場所や燃料用木材の使用が多いことについては共通しているが, 調理場の 場所, 廃棄物の廃棄場所といった点は異なっている。民族による文化や種々の環境条件が異なるためと考え られる。

\section{4 農業活動}

次に, 農業活動状況について見る。農地の所有状況ではKathmanduやRupandehi/Mun.は無回答が多

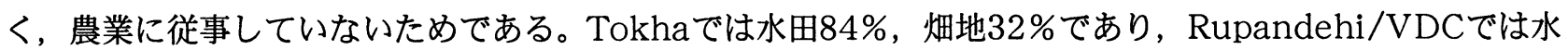
田 $48 \%$, Mustangでは畑地 $86 \%$ との回答が多い。とくに, Mustangでは水田との回答はなく, 地形的・気 候的に水田耕作が不可能となっている。また, それら農地の傾斜について, TokhaやRupandehi/VDCの水 田では「平坦」との回答が多く, Mustangの畑地で は「やや傾斜あり」と「平坦」との回答が同程度で ある。

耕作には，人力及び動物（家畜）が併用されてい る。肥料の種類では, 家畜糞と化学肥料を使用して いるとの回答が多い。ただし, Mustangでは化学肥 料との回答が他 2 地域に比べて少ない。農薬使用 は, TokhaとMustangでは半数程度, Rupandehi/ VDCでは農業に従事するところのほとんどで行われ ている。また, 図 3 に示すように農業生産性が低下 するのを防ぐためには, TokhaとRupandehi/VDC は「化学肥料・農薬の導入」, Mustangでは「新品 種の導入」と考えている人が多い。

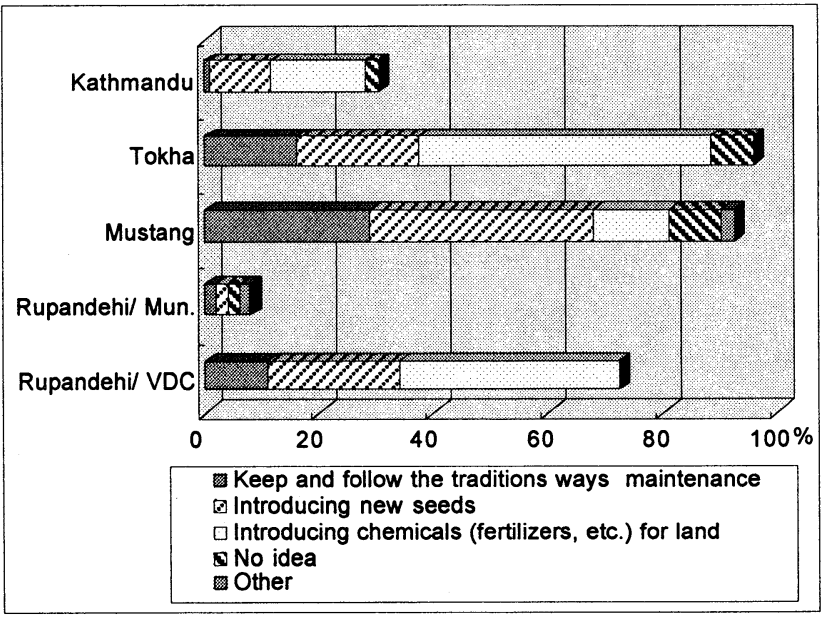

図 3 農業生産性の低下を防ぐ方法（複数回答）

\section{5 環境状況に対する認識}

図 4 に示すように居住地域での環境問題があると認識しているのは, Kathmanduで77\%, Tokhaで54 \%, Rupandehi/Mun.で67\%, Rupandehi/VDCで64\%と半数を超えている。Mustangでは12\%しかな く, 環境問題が生じていないと認識している人が多い。環境問題の種類では, Mustangを除く 4 地域で共通 して, 廃棄物による污染との回答が34〜56\%と最も多い。Kathmanduでは, 大気污染 $44 \%$, 飲料水污染 $44 \%$, 騒音・振動 $39 \%$, 悪臭39\%との回答が多い。また, Rupandehi/Mun.では, 大気污染, 廃棄物によ

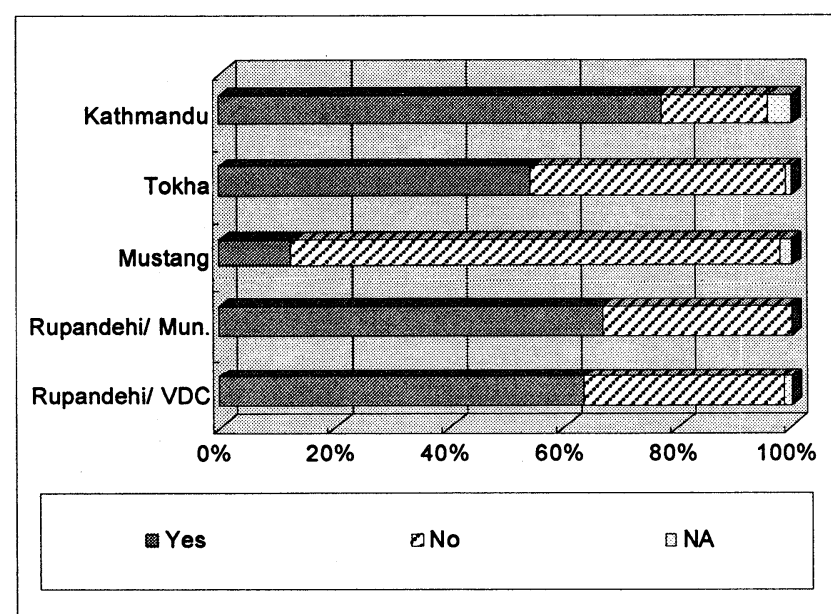

図4 環境問題の有無

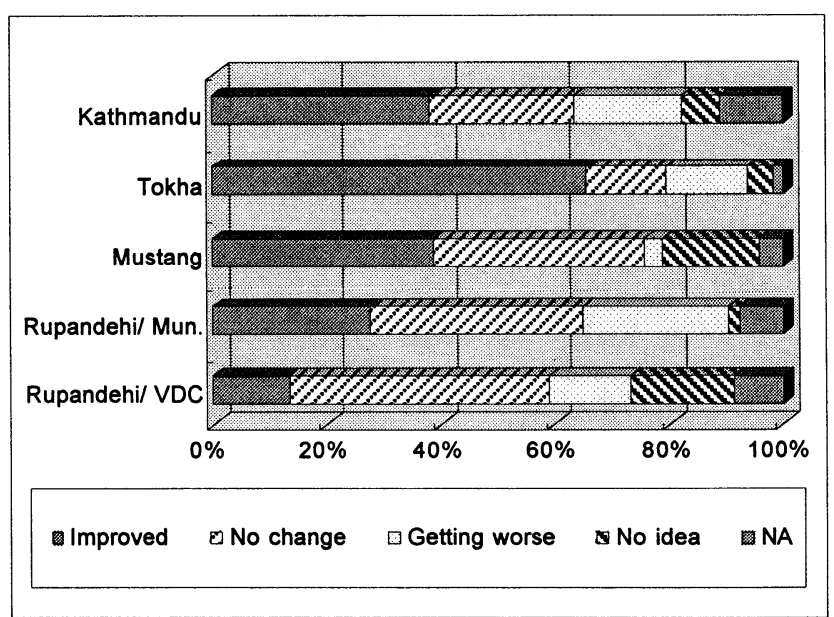

図 5 最近 5 年間での環境の変化 


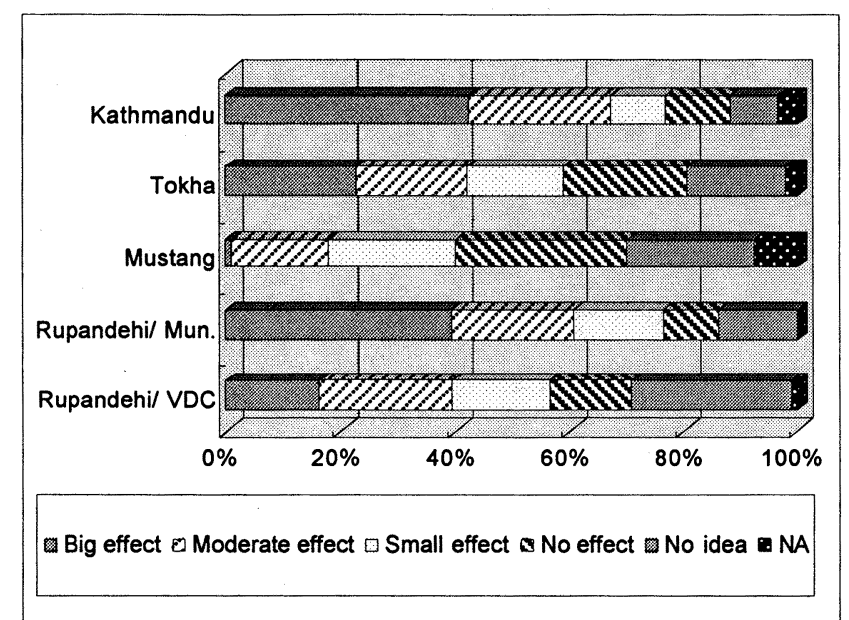

図 6 現在の環境污染の健康への影響について

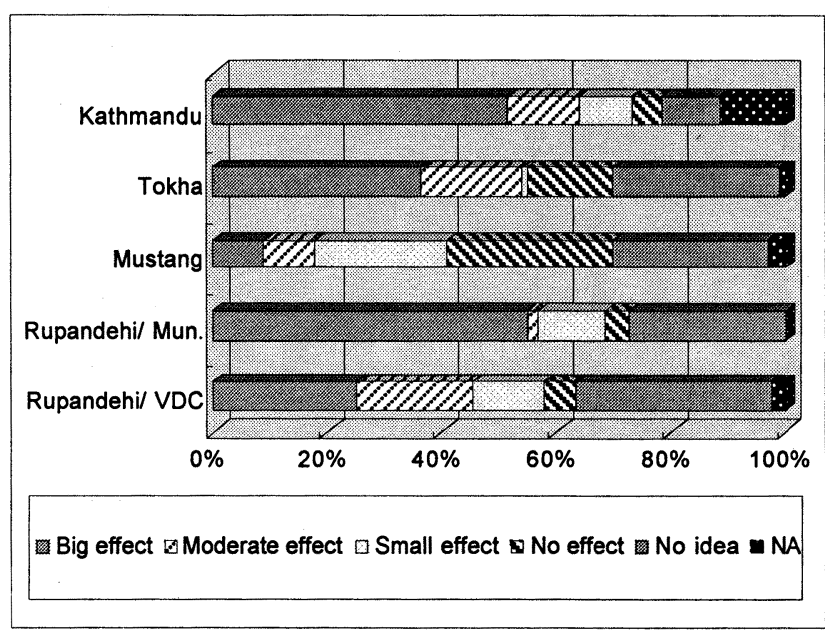

図 7 将来世代への健康影響

る污染，悪臭との回答が $43 \%$ と同数となっている。

図 5 に示した最近 5 年間での環境の変化に対しては, 各地域での回答が異なっている。Kathmanduでは 「改善した」との回答が「変化なし」や「悪化した」に比べてやや多く, Tokhaでは「改善した」との回答 が65\%と多数である。Mustangでは「改善した」と「変化なし」が拮抗している。Rupandehi/Mun.で は，「変化なし」が最も多いけれども，「改善した」と「悪化した」との回答も25\%を越えている。

Rupandehi/VDCでは「変化なし」との回答が半数近くある。

環境状況に対する認識では, 地域によって大きな違いが見られる。KathmanduやRupandehi/Mun.と いった都市部では, 大気污染や廃棄物による污染, 悪臭等の身近な環境問題に対する評価が厳しく, それら が悪化してきていると認識されている。農村地域であるTokha, Mustang, Rupandehi/VDCでは, それ ぞれ直面している環境問題が異なっているといえる。

\section{6 環境影響に対する認識}

現在の環境污染の健康への影響についての認識を図 6 に示すが, KathmanduとRupandehi/Mun.の都市 部で「大きな影響」との回答が最も多く, 逆にMustangでは「影響なし」が多くなっている。Tokha及び Rupandehi/VDCでは回答が分かれている。環境污染の原因として, いずれの地域でも住民が環境条件に配 慮していないことがあげられている。

日常の資源消費が環境にどの程度影響を与えているかについての認識では, Rupandehi/Mun.で「大き な影響|との回答が53\%と半数を超えている。KathmanduやRupandchi/VDCでも，「大きな影響」や

「中程度の影響」との回答が多い。これらに対して, Tokha及びMustangでは,「小さな影響」との回答 が多い。これらは, 各地域での実際の資源消費と現在の環境状況との関係から影響の程度が認識されてお り，各地域で異なった結果となったものと考えられる。

図 7 に示すように将来世代への健康影響に対する認識も地域によって異なる。 $\mathrm{K}$ a t h m a n d u 及び Rupandehi/Mun.では,「大きな影響」との回答が半数を超えている。TokhaやRupandehi/VDCでも 「大きな影響」との回答が最も多い。Mustangで最も多い回答は「影響なし」である。現在の環境污染の健 康への影響についての認識の結果と比べると, いずれの地域でも全体的に影響の大きな方へ回答が変動して いる。すなわち, 現在の環境污染が将来も続き, あるいはさらに悪化して, 将来世代への健康影響が増大し ていくものと考えられていると見ることができる。

\section{7 環境保全に対する意識と行動}

環境問題に関する情報源としては，いずれの地域でも「ラジオ/ テレビ」及び「保健従事者」との回答が 上位である。Mustangでは「地域リーダー」が第 1 位である。環境保全のための行動を行っているかでは, 「常に」との回答が多いのはRupandehi/Mun.(43\%)であり, Rupandehi/VDCでも「常に」29\%, 「時々」 $28 \%$ と比較的取り組まれている。TokhaやMustangでも「時々」との回答が多い。しかし, Kathmanduでは「何もしていない」との回答が $34 \%$ と最も多く, 他地域に比べるとやや消極的である。 


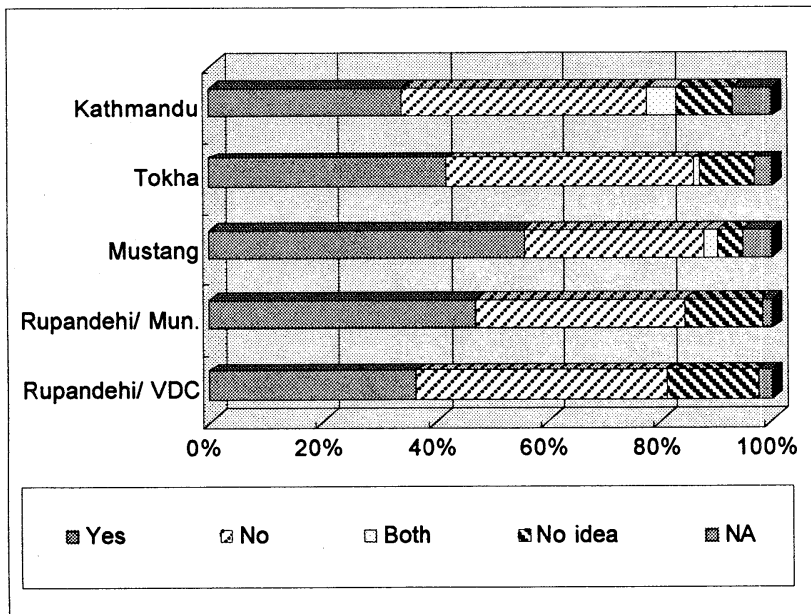

図 8 経済成長が重要との考えに対して

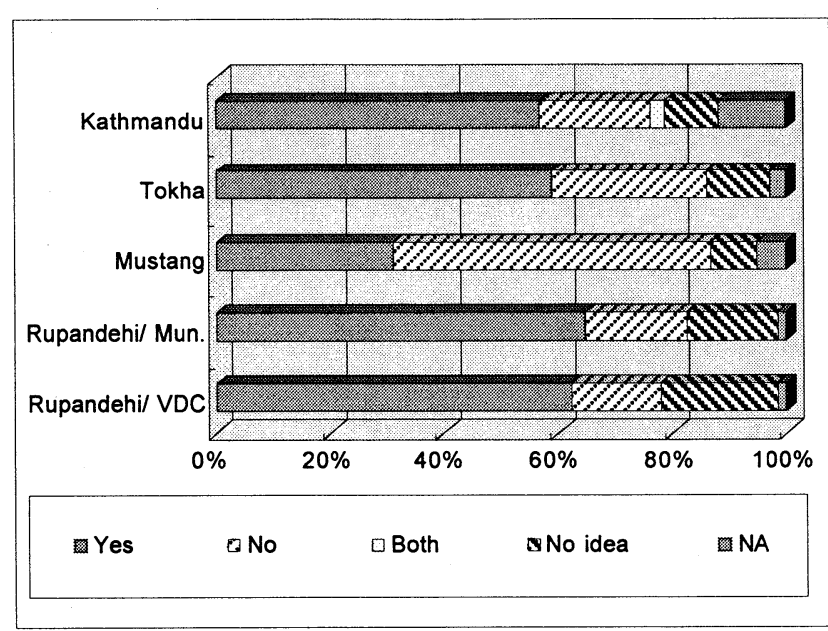

図 9 環境污染制御が重要との考えに対して

図 8 及び図 9 の経済成長と環境污染制御との関係に対する認識では, 「経済成長が重要」との回答が多い のは, Mustang とRupandehi/Mun.であり, その他の地域では「環境污染制御が重要」と考えられてい る。ただし, Rupandehi/Mun.では, 両者ともに重要と考えられているが,「環境污染制御が重要」との 回答が経済成長重視に比べて多い。

環境保全のための行動に対する認識では，「政府による行動」との回答がKathmanduを除くいずれの地 域で多い。Kathmanduでは，「環境規制のための法律を整備する」との回答が多い。また, Mustangでは いずれの方法にも半数近くの賛同が得られている。

\section{5.おわりに}

本研究は, 開発途上国であるネパールを対象にして社会経済の状況及び環境污染状況との関係において地域 住民の環境に対する意識形成過程を明らかにし, 環境資源の持続性の側面から睘境政策の方向を検討すること を目的として行ったものである。ネパールは多民族国家であり, 地域によって宗教や民族構成が大きく異なる ために地形等の自然条件と重複して生活や農業生産様式に地域的な変化を与えていること,室内環境での大気 污染及び都市部での飲料水污染がみられること, 地域によって環境問題への認識が異なることを示した。しか し,これら諸条件相互の関係を解析した上での地域住民の環境意識形成過程の検討, さらには環境政策の方向 の検討までには至らなかった。Kathmandu市内では, 自動車排ガスによる大気污染を防止するために, 海外 からの援助を受けて電気自動車の導入も進められている。今後は, こうした環境改善のための取り組みも考慮 に入れた環境資源に関する検討を進めていきたい。

なお, 本研究は文部省科学研究費（国際学術研究, 課題番号 09041174 , 研究代表者柏崎浩) の補助を受け て行ったものであり, 関係各位に感謝の意を表する。また, 大気污染物質の分析に際してご協力いただいた産 業医科大学嵐谷奎一, 保利一, 石田尾徹の各氏に深く感謝する。

\section{参考文献}

[1] 環境庁「環境勘定検討会」: 環境勘定に関する基礎調査および包括的環境勘定体系（CASE）の開発, 環境 庁「環境勘定検討会」報告, 1998.3

[2] 世界資源研究所・国連環境計画・国連開発計画・世界銀行: 世界の資源と環境 1998-99, 中央法規, 1998.11

[3] 財団法人国際協力推進協会 : ネパール，開発途上国国別経済協カシリーズ第 5 版, 1997.3

[4] Nepal South Asian Centre: Nepal Human Development Report 1998, Nepal South Asian Centre, 1998.7

[5] Central Bureau of Statistics: Statistical Year Book of Nepal 1997, 1997.6

[6] H. Hori et. al.: $\mathrm{NO}_{2}$ AND VOLATILE ORGANIC COMPOUND EXPOSURE LEVEL IN NAPALES AND JAPANESE, Proc. of the 8th International Conference on Indoor Air Quality \& Climate, The Intenational Academy of Indoor Air Sciences, 1999.8(印刷中) 